\title{
In Vitro and Computational Studies of Perezone and Perezone Angelate as Potential Anti-Glioblastoma Multiforme Agents
}

\author{
Maricarmen Hernández-Rodríguez $\left.{ }^{1}{ }^{(}\right)$, Pablo I. Mendoza Sánchez ${ }^{2}$, Joel Martínez ${ }^{3}{ }^{\circledR}$, Martha E. Macías Pérez ${ }^{4}$, \\ Erika Rosales Cruz ${ }^{5}$, Teresa Żołek ${ }^{6}$, Dorota Maciejewska ${ }^{6}$, René Miranda Ruvalcaba ${ }^{2}$, Elvia Mera Jiménez ${ }^{1, *}$ \\ and María I. Nicolás-Vázquez ${ }^{2, *}$ [1]
}

check for updates

Citation: Hernández-Rodríguez, M.; Mendoza Sánchez, P.I.; Martínez, J.; Macías Pérez, M.E.; Rosales Cruz, E.; Żołek, T.; Maciejewska, D.; Miranda Ruvalcaba, R.; Mera Jiménez, E.; Nicolás-Vázquez, M.I. In Vitro and Computational Studies of Perezone and Perezone Angelate as Potential Anti-Glioblastoma Multiforme Agents. Molecules 2022, 27, 1565. https://doi.org/10.3390/ molecules27051565

Academic Editors: Lee Wei Lim and Luca Aquilito

Received: 6 February 2022

Accepted: 23 February 2022

Published: 26 February 2022

Publisher's Note: MDPI stays neutral with regard to jurisdictional claims in published maps and institutional affiliations.

Copyright: (c) 2022 by the authors Licensee MDPI, Basel, Switzerland. This article is an open access article distributed under the terms and conditions of the Creative Commons Attribution (CC BY) license (https:// creativecommons.org/licenses/by/ $4.0 /)$.
1 Laboratorio de Cultivo Celular, Escuela Superior de Medicina, IPN, Salvador Díaz Mirón esq. Plan de San Luis s/n, Casco de Santo Tomas, Miguel Hidalgo, Ciudad de Mexico 11340, Mexico; dra.hernandez.ipn@gmail.com

2 Departamento de Ciencias Químicas, Facultad de Estudios Superiores Cuautitlán Campo 1, UNAM. Av. Primero de Mayo S/N, Sta María Guadalupe las Torres, Cuautitlán Izcalli 54740, Mexico; pimendozas1@gmail.com (P.I.M.S.); mirruv@yahoo.com.mx (R.M.R.)

3 Facultad de Ciencias Químicas, Universidad Autónoma de San Luis Potosí, San Luis Potosí 78210, Mexico; atlanta126@gmail.com

4 Unidad de Investigación Biomédica de Zacatecas (UIBMZ) del Instituto Mexicano del Seguro Social (IMSS), Alameda Trinidad García de La Cadena 438_2436A436, Zacatecas Centro, Zacatecas 98000, Mexico; marthita_e23@yahoo.com.mx

5 Laboratorio de Hematopatología, Escuela Nacional de Ciencias Biológicas, IPN, Prolongación de Carpio y, Calle Plan de Ayala s/n, Santo Tomás, Miguel Hidalgo, Ciudad de Mexico 11340, Mexico; erika_encb@hotmail.com

6 Department of Organic Chemistry, Faculty of Pharmacy, Medical University of Warsaw, Żwirki i Wigury 61, 02-091 Warszawa, Poland; teresa.zolek@wum.edu.pl (T.Ż.); dorota.maciejewska77@gmail.com (D.M.)

* Correspondence: elviamj@gmail.com (E.M.J.); nicovain@yahoo.com.mx (M.I.N.-V.)

\begin{abstract}
Glioblastoma multiforme (GBM) represents the most malignant type of astrocytoma, with a life expectancy of two years. It has been shown that Poly (ADP-ribose) polymerase 1 (PARP-1) protein is over-expressed in GBM cells, while its expression in healthy tissue is low. In addition, perezone, a phyto-compound, is a PARP-1 inhibitor with anti-neoplastic activity. As a consequence, in the present study, both in vitro and computational evaluations of perezone and its chemically related compound, perezone angelate, as anti-GBM agents were performed. Hence, the anti-proliferative assay showed that perezone angelate induces higher cytotoxicity in the GBM cell line $\left(\mathrm{U} 373 \mathrm{IC}_{50}=6.44 \mu \mathrm{M}\right)$ than perezone $\left(\mathrm{U} 373 \mathrm{IC}_{50}=51.20 \mu \mathrm{M}\right)$ by induction of apoptosis. In addition, perezone angelate showed low cytotoxic activity in rat glial cells $\left(\mathrm{IC}_{50}=173.66 \mu \mathrm{M}\right)$. PARP-1 inhibitory activity $\left(\mathrm{IC}_{50}=5.25 \mu \mathrm{M}\right)$ and oxidative stress induction by perezone angelate were corroborated employing in vitro studies. In the other hand, the performed docking studies allowed explaining the PARP-1 inhibitory activity of perezone angelate, and ADMET studies showed its probability to permeate cell membranes and the blood-brain barrier, which is an essential characteristic of drugs to treat neurological diseases. Finally, it is essential to highlight that the results confirm perezone angelate as a potential anti-GBM agent.
\end{abstract}

Keywords: phyto-compounds; computational studies; drug-likeness; anti-neoplastic activity; glioblastoma multiforme

\section{Introduction}

Glioblastoma multiforme (GBM) represents the most malignant type of astrocytoma, which is distinguished by its high ability to produce metastasis. Patients with GBM have the worst prognosis [1-4]. Nowadays, GBM treatment includes surgery, radiotherapy, and chemotherapy, which have shown minimal improvements [5]. Moreover, local GBM infiltration into normal tissue results in tumor recurrence, culminating with the patient's death [6]. Hence, chemotherapy represents a valuable tool to treat GBM. Nevertheless, 
its efficacy is diminished by the blood-brain barrier (BBB) that restring the diffusion of therapeutic compounds to the brain [7]. The principal treatments employed only increased the life expectancy of GBM patients to fifteen months [8]. Consequently, the design of novel directed therapies for GBM results are of great interest.

Poly ADP-ribose polymerase 1 (PARP-1) protein represents a promising target for developing of anti-neoplastic compounds. PARP-1 is best known for its role in deoxyribonucleic acid (DNA) single-strand breaks repair; therefore, PARP-1 inhibition avoids DNA repair and the induction of death of cancer cells [9].

Recently, immunohistochemical studies showed that PARP-1 is overexpressed in GBM cells, being practically undetectable in normal brain tissue [10]. This fact has allowed the search for novel diagnostic tools for GBM by synthesizing a small molecule based on radio iodinated PARP-1 targeted tracers [11]. Additionally, higher PARP-1 levels have exhibited an inverse correlation with patient survival [12]. This fact emphasizes the importance of PARP-1 inhibitors as a potential drug for the treatment of GBM. In this sense, perezone, a phyto-compound extracted from roots of the plant of the genus Acourtia, has exhibited anti-neoplastic activity by PARP-1 inhibition and reactive oxygen species release [13]. For this reason, the present research work aimed to perform in vitro and computational evaluation of perezone and its chemically related compound, perezone angelate (Figure 1), as anti-GBM agents.<smiles>CC(C)=CCCC(C)C1=C(O)C(=O)C(C)=CC1=O</smiles>

3-hydroxy-5-methyl-2-(6-methylhept-5-en-2-yl)cyclohexa-2,5diene-1,4-dione

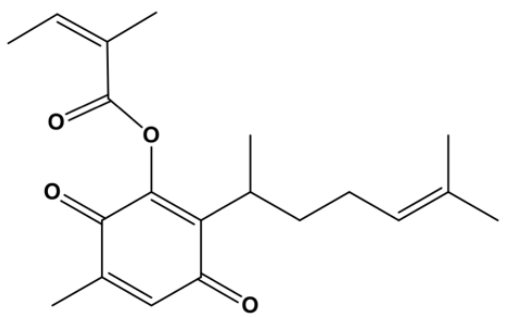

(Z)-5-methyl-2-(6-methylhept-5-en-2-yl)-3,6-dioxocyclohexa -1,4-dien-1-yl 2-methylbut-2-enoate

\section{Perezone angelate}

Figure 1. Chemical structures of perezone and perezone angelate.

\section{Results}

\subsection{Extraction of Perezone and Perezone Angelate}

The extraction of perezone and perezone angelate from roots of Acourtia cordata was performed as previously described [13]. Physical and spectroscopic data were correlated with the literature [14].

Perezone: Yellow crystalline solid, $\mathrm{R}_{\mathrm{f}}=0.42$ ( $n$-hexane/AcOEt 9:1), $\mathrm{mp}=104 \pm 1{ }^{\circ} \mathrm{C}$, ${ }^{1} \mathrm{H} \mathrm{NMR}\left(300 \mathrm{MHz}, \mathrm{CDCl}_{3}\right) \delta(\mathrm{ppm}): 1.20(\mathrm{~d}, J=7.1 \mathrm{~Hz}, 3 \mathrm{H}), 1.53(\mathrm{~s}, 3 \mathrm{H}), 1.58(\mathrm{~m}, 1 \mathrm{H}), 1.64$ $(\mathrm{s}, 3 \mathrm{H}), 1.80(\mathrm{~m}, 1 \mathrm{H}), 1.86(\mathrm{dt}, J=21.1,7.0 \mathrm{~Hz}, 1 \mathrm{H}), 1.92(\mathrm{~m}, 1 \mathrm{H}), 2.06(\mathrm{~d}, J=1.6 \mathrm{~Hz}, 3 \mathrm{H})$, $3.05(\mathrm{~m}, 1 \mathrm{H}), 5.07(\mathrm{dd}, J=10.0,4.1 \mathrm{~Hz}, 1 \mathrm{H}), 6.48(\mathrm{~d}, J=1.6 \mathrm{~Hz}, 1 \mathrm{H}), 6.99(\mathrm{~s}, 1 \mathrm{H}) ;{ }^{13} \mathrm{C} \mathrm{NMR}$ (75 MHz, $\mathrm{CDCl}_{3}$ ) $\delta$ (ppm): 14.71, 17.63, 18.24, 25.70, 26.69, 29.33, 34.11, 124.48, 124.59, 131.45, $135.88,140.55,150.98,184.34,187.39$; ESI-HRMS (19 eV), exact mass for $\mathrm{C}_{15} \mathrm{H}_{21} \mathrm{O}_{3},[\mathrm{M}+\mathrm{H}]^{+}$ 249.14907 Da, corresponding accurate value: $249.14966 \mathrm{Da}$, error: + 0.59, insaturations: 5.5.

Perezone angelate: Yellow oil, $\mathrm{R}_{\mathrm{f}}=0.49$ (n-hexane/AcOEt 9:1), ${ }^{1} \mathrm{H}$ NMR $(300 \mathrm{MHz}$, $\left.\mathrm{CDCl}_{3}\right) \delta(\mathrm{ppm}): 1.08(\mathrm{~d}, J=7.2 \mathrm{~Hz}, 3 \mathrm{H}), 1.53(\mathrm{~s}, 3 \mathrm{H}), 1.60(\mathrm{~m}, 1 \mathrm{H}), 1.63(\mathrm{~s}, 3 \mathrm{H}), 1.82(\mathrm{~m}$, $1 \mathrm{H}), 1.90(\mathrm{dt}, J=21.3,7.0 \mathrm{~Hz}, 1 \mathrm{H}), 1.92(\mathrm{~m}, 1 \mathrm{H}), 2.05$ (quintet, $J=1.5,3 \mathrm{H}), 2.06(\mathrm{~d}, J=1.6 \mathrm{~Hz}$, 3H), 2.07 (dd, $J=7 \mathrm{~Hz}, 1.5 \mathrm{~Hz}, 3 \mathrm{H}), 2.99(\mathrm{~m}, 1 \mathrm{H}), 5.02(\mathrm{dd}, J=10.0,4.1 \mathrm{~Hz}, 1 \mathrm{H}), 6.33$ (q, $J=7 \mathrm{~Hz}, 1 \mathrm{H}), 6.48(\mathrm{~d}, J=1.6 \mathrm{~Hz}, 1 \mathrm{H}) ;{ }^{13} \mathrm{C} \mathrm{NMR}\left(75 \mathrm{MHz}, \mathrm{CDCl}_{3}\right) \delta(\mathrm{ppm}): 15.27,15.98$, $17.67,18.63,20.50,22.41,25.69,26.55,34.68$, two overlapping signals at 124.03, 126.08, $131.97,134.11,139.92,142.43,143.76,170.16,180.73,186.89$; ESI-HRMS (19 eV), exact mass 
for $\mathrm{C}_{20} \mathrm{H}_{27} \mathrm{O}_{4},[\mathrm{M}+\mathrm{H}]^{+} 331.1904 \mathrm{Da}$, corresponding accurate value: $331.1945 \mathrm{Da}$, error: 9.3796, unsaturations: 7.5.

\subsection{Perezone Angelate Showed Greater Cytotoxic Activity in U373 Cells than Normal Rat Glial Cells}

Cytotoxic evaluation of perezone and perezone angelate was performed in U373 cells, considering its pro-apoptotic effect, as previously reported [13], employing suberoylanilide hydroxamic acid as a positive control. Figure 2a shows the cytotoxic activity of suberoylanilide hydroxamic acid, with an $85.8 \%$ viability at $10 \mu \mathrm{M}$, similar to data previously reported [15]. According to the results, it is possible to observe that perezone and perezone angelate showed cytotoxic activity dependent on concentration (Figure 2a,b). The cytotoxic activity of perezone angelate ( $\mathrm{IC}_{50}$ of $6.44 \pm 1.6 \mu \mathrm{M}$ ) was higher (Figure 2a) in comparison to perezone ( $\mathrm{IC}_{50}$ of $\left.51.20 \pm 0.3 \mu \mathrm{M}\right)$ in the $\mathrm{U} 373$ cell line. For mixed glial cell culture, perezone showed an $\mathrm{IC}_{50}$ of $59.85 \pm 0.3 \mu \mathrm{M}$ (Figure $2 \mathrm{~b}$ ), which was very similar to that found in the U737, while perezone angelate showed an $\mathrm{IC}_{50}$ of $173.66 \pm 1.6 \mu \mathrm{M}$ (Figure $2 \mathrm{~b}$ ). However, although perezone angelate showed cytotoxicity in mixed glial cell culture, the $\mathrm{IC}_{50}$ of this compound was twenty-six times lower in U373 cells, thus demonstrating its anti-neoplastic effect.

a)

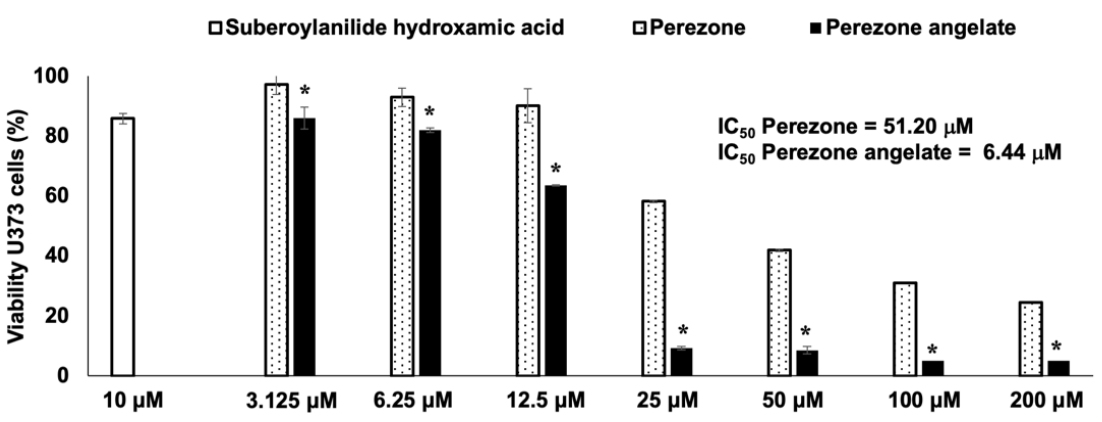

b)

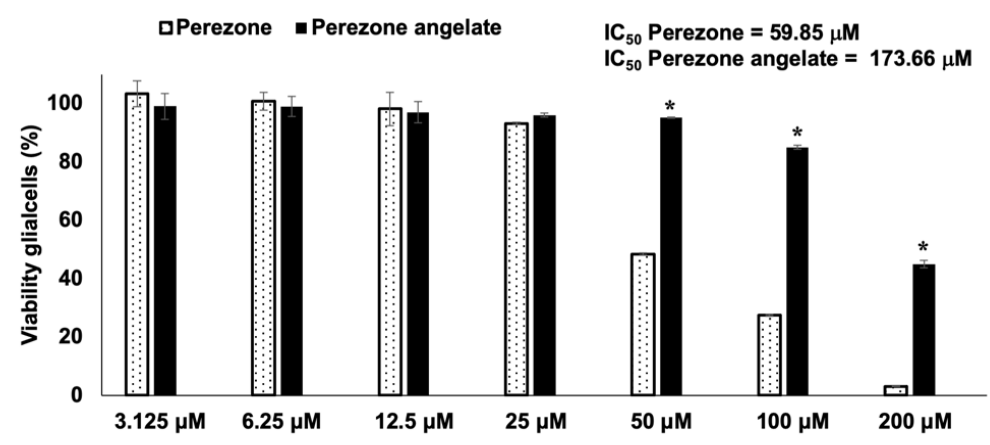

Figure 2. Graph bar of cytotoxic activity of perezone and perezone angelate in the GBM U373 cell line (a) and mixed glial cell culture (b). U373 cells $\left(5 \times 10^{4}\right.$ cells/well) and mixed glial cells $\left(5 \times 10^{4}\right.$ cells/well) were incubated without (control) and with crescent concentrations of the studied compounds during $48 \mathrm{~h}(n=8)$, employing suberoylanilide hydroxamic acid $(10 \mu \mathrm{M})$ as a positive control. At the end of the incubation, an MTT assay was performed to determine the viability of cells under treatment. Each bar in the graph indicates percentage means and standard error of the mean, statistical differences were calculated by one-way ANOVA * $p<0.05$, (between perezone and perezone angelate at each concentration of tested compounds). Perezone angelate showed higher cytotoxic activity in U373 cells than perezone and lower cytotoxic activity in mixed glial cells than perezone. 


\subsection{Perezone Angelate Induces Apoptosis in U373 Cells}

According to the obtained results, it is possible to observe that perezone and perezone angelate increase cells marked with Annexin V-FITC+/7AAD, establishing that cells were under apoptosis (Figure 3a). Furthermore, the percentage of apoptotic cells was statistically significant higher for perezone angelate than for perezone (Figure $3 b$ ), and apoptosis induction is preferred over necrosis by anti-neoplastic agents [16]. The achieved results emphasize the importance of perezone angelate.

a)

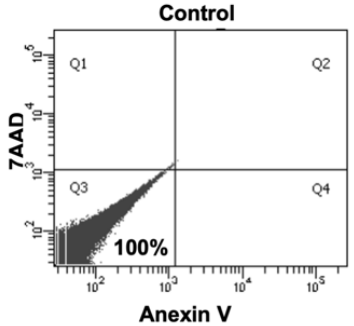

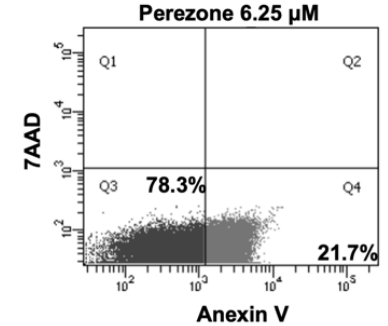

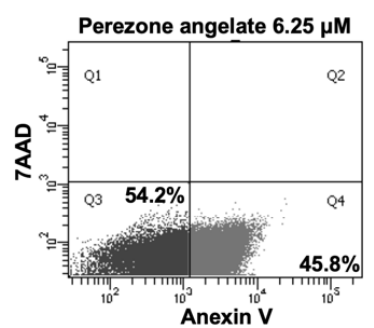

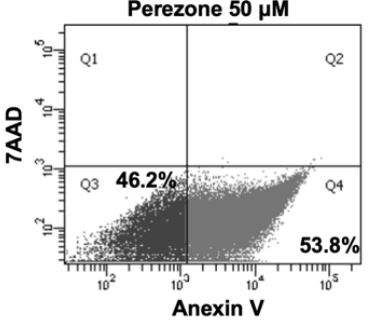

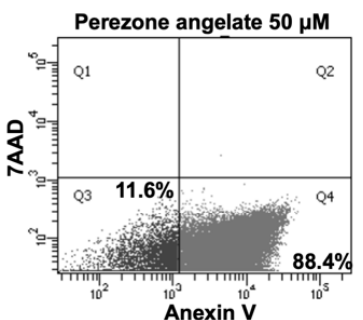

b)

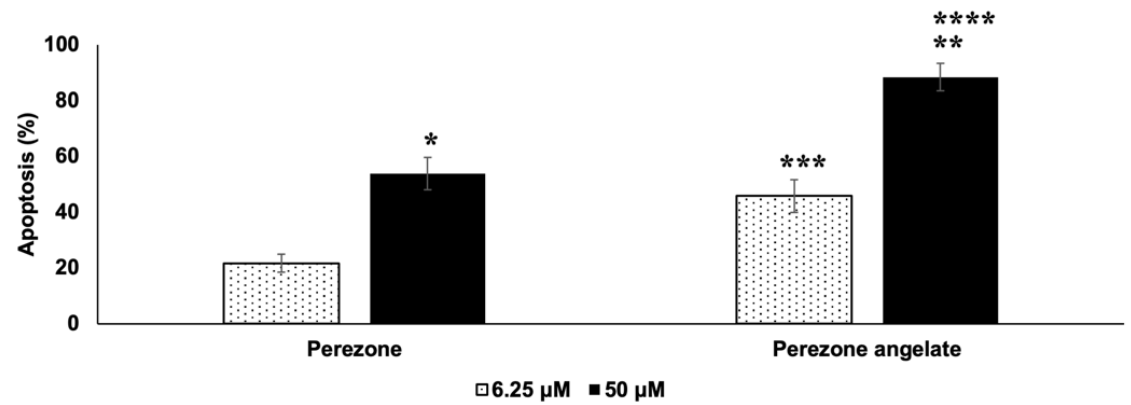

Figure 3. U373 cells were marked with Annexin V-FITC+/7AAD- (apoptotic) under perezone and perezone angelate treatment. Cells were incubated in the absence and presence of studied compounds for $48 \mathrm{~h}$ at 6.25 and $50 \mu \mathrm{M}(n=3)$. After Annexin-V/7-AAD staining, cells were analyzed by flow cytometry. (a) Representative histograms and the percentage of apoptotic U373 cells; (b) In the graph bar, each one indicates the percentage of mean apoptotic cells \pm SEM, statistical differences were calculated by one-way ANOVA followed by a Tukey post hoc test, ${ }^{*} p<0.05$ between perezone $6.25 \mu \mathrm{M}$ and perezone $50 \mu \mathrm{M},{ }^{* *} p<0.05$ between perezone angelate $6.25 \mu \mathrm{M}$ and perezone angelate $50 \mu \mathrm{M},{ }^{* * *} p<0.05$ between perezone $6.25 \mu \mathrm{M}$ and perezone angelate $6.25 \mu \mathrm{M},{ }^{* * * *} p<0.05$ between perezone $50 \mu \mathrm{M}$ and perezone angelate $50 \mu \mathrm{M}$. The induction of apoptosis was higher to perezone angelate in comparison to perezone.

\subsection{Perezone and Perezone Angelate Inhibit U373 Cell Migration}

Preventing the invasiveness and metastasis in cancer is a challenge that requires urgent solutions, especially in the case of GBM [17]. For this reason, the evaluation of migration of U373 under treatment with perezone angelate and perezone at low concentrations $(6.25 \mu \mathrm{M})$ was performed. As can be seen in Figure 4, U373 cells in control groups reach confluence and cover the wound space; in contrast, fewer U373 cells migrated in the groups treated with perezone and perezone angelate (Figure $4 \mathrm{a}$ ), and consequently, the percentage of area covered by migration of the U373 cells treated with studied compounds was significantly 
lower to the control. However, there were no differences in the percentage of the covered area by migrating cells between both compounds (Figure $4 b$ ).

a)

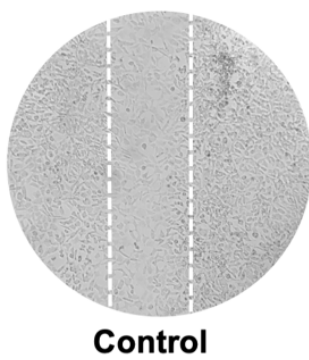

b)

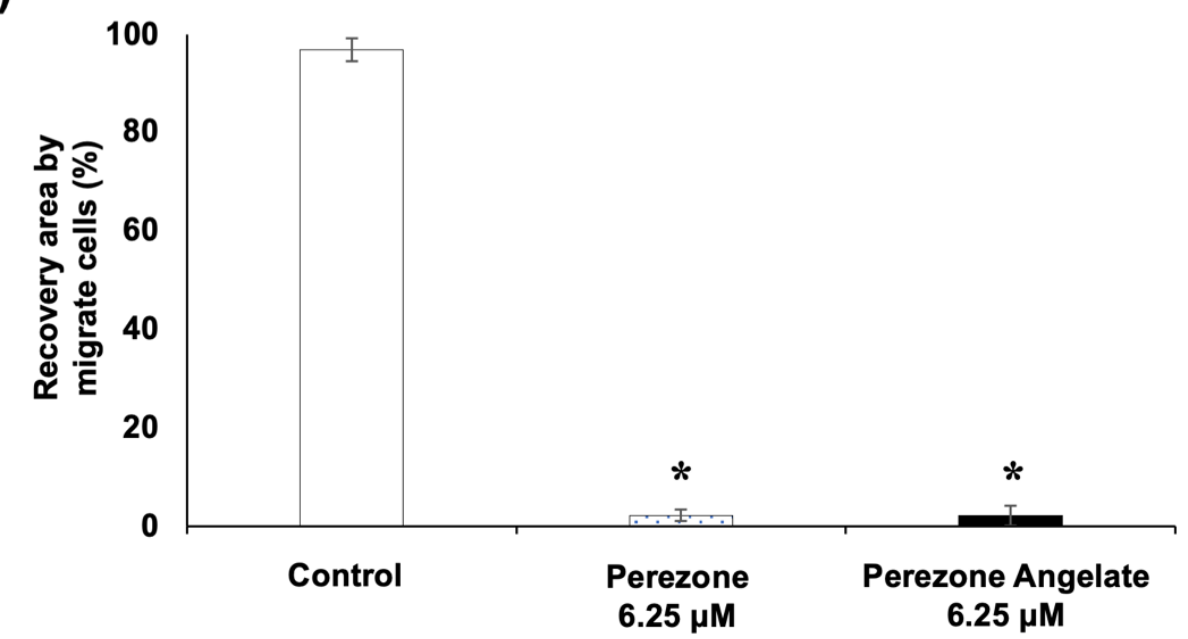

Figure 4. U373 cell migration in vitro is inhibited by perezone and perezone angelate. Wounds with a sterile tip were completed after cells reached confluence. Wound closure was quantified in the absence and presence of studied compounds after $48 \mathrm{~h}$ of treatment $(n=3)$ : (a) Representative image $(40 \times)$ of U373 cells under treatment; (b) the bars express the average percentage of the covered area and the vertical lines express the \pm SEM. Statistical analysis was performed by one-way ANOVA and Tukey's post hoc test * $p<0.05$ (between control and treatments).

\subsection{Perezone Angelate Is a PARP-1 Inhibitor}

As it can be seen in Figure 5, the potent inhibition of PARP-1 by olaparib was confirmed with an $\mathrm{IC}_{50}$ of $5.5 \mathrm{nM}( \pm 0.3 \mu \mathrm{M})$, which is in accordance with the literature [18]. Importantly, PARP-1 inhibitory activity by perezone angelate was confirmed, with an $\mathrm{IC}_{50}$ of $5.25 \mu \mathrm{M}( \pm 1.2 \mu \mathrm{M})$, in this way, showing a higher potency than perezone [13].

\subsection{Perezone and Perezone Angelate Increases Reactive Oxygen Species (ROS) Production in} U373 Cells

ROS production was measured by the fluorescent DCFH-DA technique. As shown in Figure 6, the treatment of U373 cells with perezone and perezone angelate induces ROS production in a dose-dependent manner with both compounds, compared to the control group. The induction of a more oxidized status was similar for both compounds did not show statistically significant differences. 


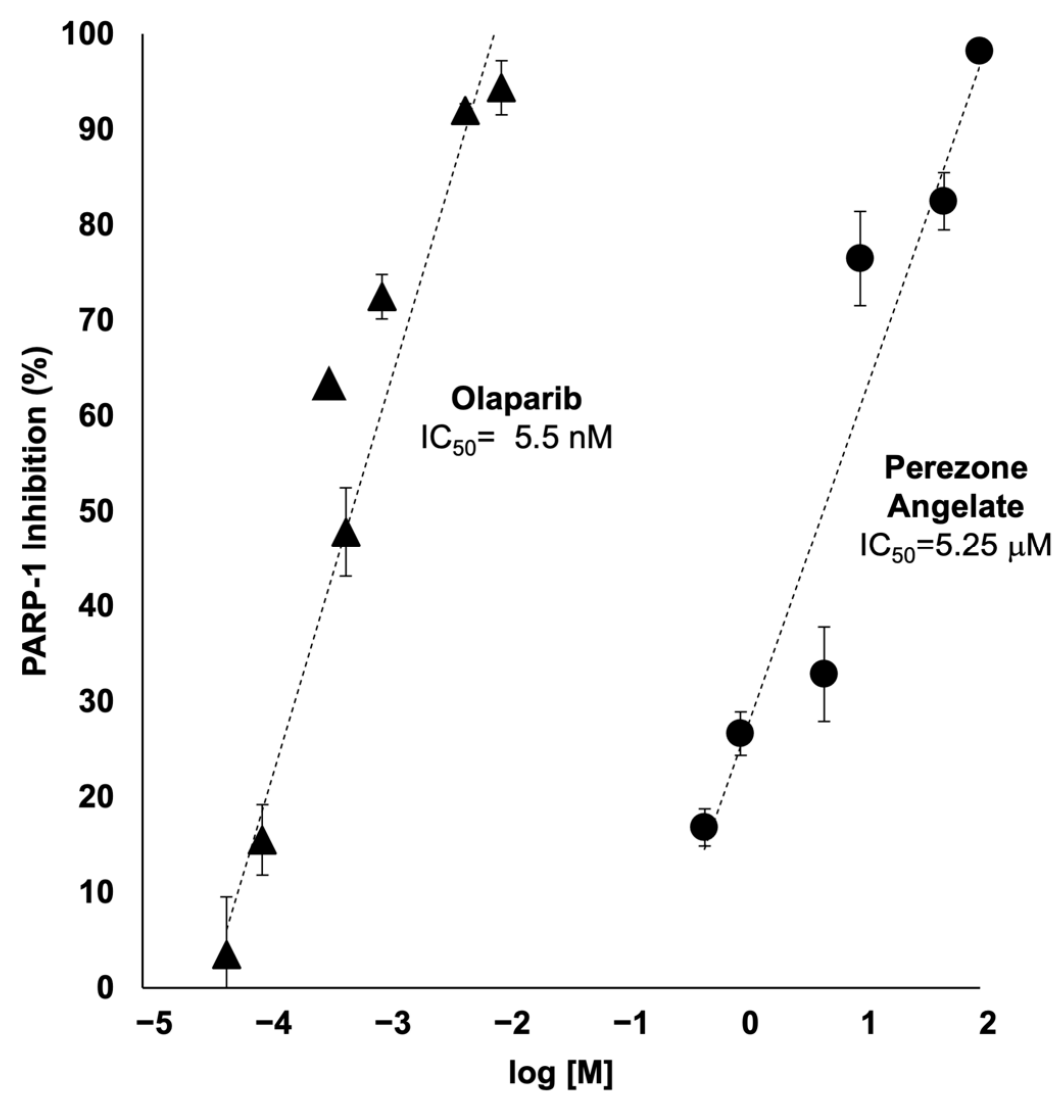

Figure 5. PARP-1 inhibition activity of perezone angelate (circles) and olaparib (triangles). According to the manufacturer's instructions (PARP-1 colorimetric assay kit BPS Bioscience, USA, Catalog Number 80580). Values on the graph represent mean values, and vertical bars denote standard error $(n=3)$. The half maximal inhibitory concentration $\left(\mathrm{IC}_{50}\right)$ was estimated for each compound through linear regression analysis.

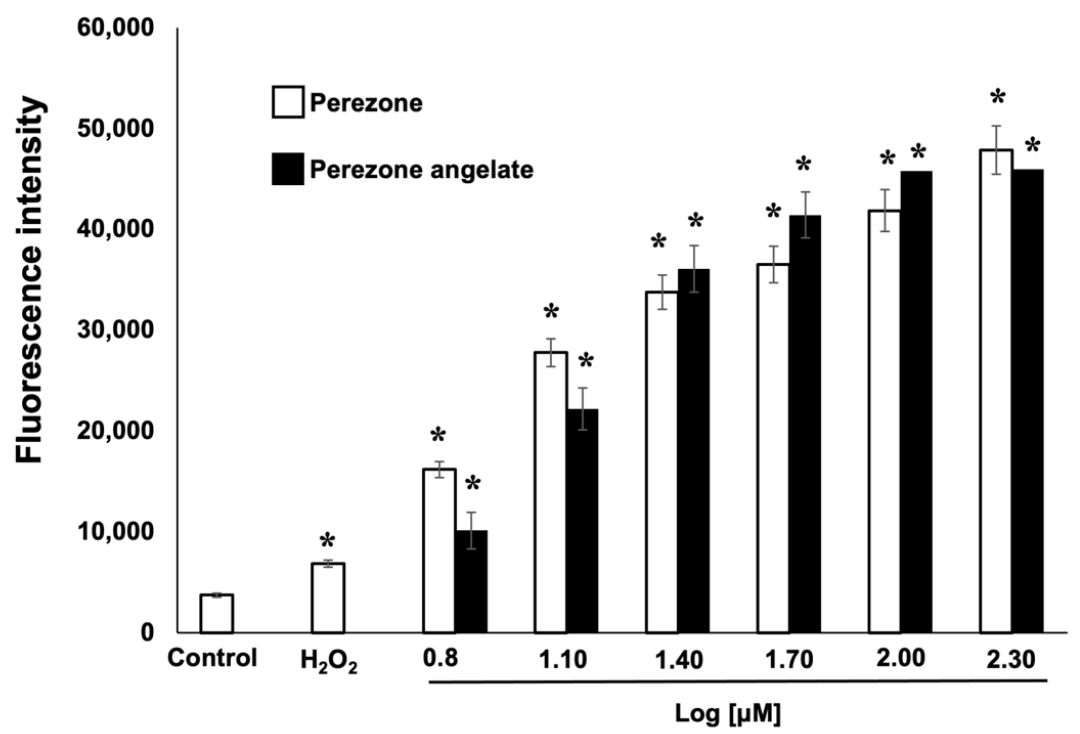

Figure 6. ROS production in U373 cells treated for $48 \mathrm{~h}$ with increasing perezone and perezone angelate concentrations evidenced by flow cytometry analysis of DCFH-DA staining $(n=3)$. Bars represent mean \pm SEM. Statistical differences were calculated by one-way ANOVA, and Tukey's post hoc test, ${ }^{*} p<0.05$ (between control and treatments). 


\subsection{Perezone Angelate Interacts with the PARP-1 Active Site Revealed by Docking Studies}

Traditionally, the design of novel PARP-1 inhibitors is aimed to target several of 50 amino acid residues located at the PARP-1 active site [19]. Since it was reported that PARP-1 presents high stability, the conformer obtained from PDB was employed to perform docking studies [20]. Results displayed that perezone angelate interacts with the catalytic site of PARP-1, as can be seen in Figure 7. As a measure of affinity to PARP-1, $\Delta \mathrm{G}$ values obtained by each compound are shown in Figure 7. As expected, perezone angelate showed the highest affinity $(-9.39 \mathrm{kcal} / \mathrm{mol})$.

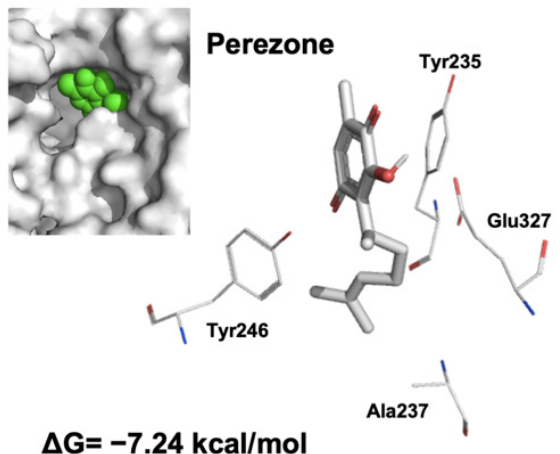

$\Delta \mathrm{G}=-7.24 \mathrm{kcal} / \mathrm{mol}$

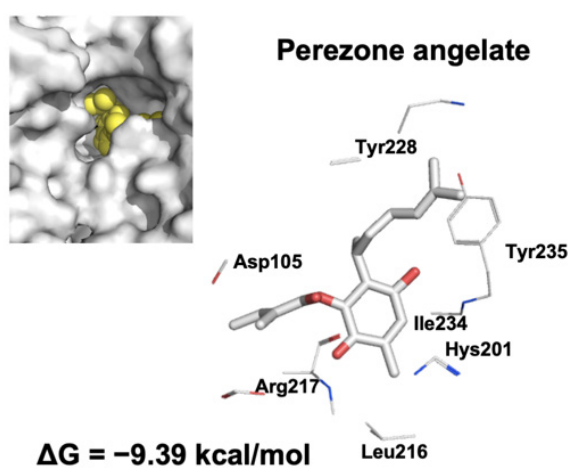

$\Delta \mathbf{G}=-9.39 \mathrm{kcal} / \mathrm{mol} \quad$ Leu216

Figure 7. Non-bonding interactions established by perezone and perezone angelate with PARP-1, demonstrated by docking studies, the volume occupied by each compound in the catalytic site of PARP-1 is shown at the left of each image. Perezone angelate showed the highest affinity; the presence of its angelic substituent allowed it to present a different binding mode and exhibit higher affinity than perezone.

The binding modes of perezone and perezone angelate with the catalytic site of PARP1 are shown in Figure 7 . The presence of an angelic substituent in perezone angelate results in an increase in affinity to PARP-1 in comparison with perezone $(\Delta \mathrm{G}=-9.39$ and $-7.24 \mathrm{kcal} / \mathrm{mol}$, respectively); the energy difference shown between both compounds is $2.15 \mathrm{kcal} / \mathrm{mol}$.

Perezone establishes hydrogen bonds with the lateral chain of Tyr235, Glu327, and Tyr246 and hydrophobic interactions with Ala237 (Figure 7). In comparison, the presence of the angelic substituent in perezone angelate allows to change the binding mode and consequently create non-bonding interactions with Tyr228, Tyr235, Ile234, Hys201, Leu216, Arg217, and Asp105.

\subsection{Perezone Angelate Showed a High Probability to Permeate Cells and Cross the BBB According to ADMET Predictions}

In silico ADMET study was performed for perezone and perezone angelate. The values obtained for Lipinski's rule of five, topological polar surface area (TPSA), and the solubility $\left(S_{\mathrm{W}}\right)$ are summarized in Table 1. The molecular weights (MWt) are defined for orally available compounds. The calculated logarithm of the 1-octanol-water partition coefficient $(\log \mathrm{P})$ values for perezone (3.336) and perezone angelate (4.478) indicate that these can be absorbed ( $\log \mathrm{P}<5$ ). The distribution coefficient ( $\log \mathrm{D})$ values, which give an estimate for ionizable forms of a drug, were calculated at a $\mathrm{pH}$ of 7.4. The $\log$ $\mathrm{D}$ values for perezone angelate exceeded the traditional cutoff value of 4.0 , indicating a higher probability of binding to plasma proteins [21]. The number of atoms engaged in the intermolecular hydrogen bonding and the number of rotatable bonds are within the usually acceptable ranges. TPSA is a good descriptor of absorption, including intestinal absorption, bioavailability, and BBB penetration [22]. TPSA values for studied compounds were found below $90 \AA^{2}$, thus predicting favorable conditions for the penetration the BBB, which is essential for the interaction of the ligand with brain targets. The water solubility 
$\left(S_{\mathrm{w}}\right)$ values for studied compounds show acceptable solubility, and we can suppose that the analyzed compounds are potentially promising agents for advanced biological screening.

Table 1. Parameters joined with Lipinski's rule of five, the theoretical values of the topological polar surface area (TPSA), and water solubility $\left(\mathrm{S}_{\mathrm{W}}\right)$ for perezone and perezone angelate.

\begin{tabular}{|c|c|c|c|c|c|c|c|}
\hline \multirow{3}{*}{ Compound } & MWt & $\log P$ & $\log D$ & HBD & HBA & \multirow{2}{*}{ TPSA } & \multirow{2}{*}{$S_{w}$} \\
\hline & \multicolumn{5}{|c|}{ Expected Values } & & \\
\hline & $(\leq 450 \mathrm{~g} / \mathrm{mol})$ & $(\leq 5)$ & $(\leq 4)$ & $(\leq 3)$ & $(\leq 7)$ & $\left(140 \AA^{2}\right)$ & $(\geq 0.010 \mathrm{mg} / \mathrm{mL})$ \\
\hline \multirow{2}{*}{$\begin{array}{l}\text { Perezone } \\
\text { Perezone } \\
\text { angelate }\end{array}$} & 248.32 & 3.336 & 0.883 & 1 & 3 & 54.37 & 0.118 \\
\hline & 330.43 & 4.478 & 4.478 & 0 & 4 & 60.44 & 0.010 \\
\hline
\end{tabular}

MWt: molecular weight; Log P: calculated logarithm of the 1-octanol-water partition coefficient (neutral species); Log D: the distribution coefficient, $\mathrm{D}$, is the appropriate descriptor for non-ionized and ionizable compounds at a given $\mathrm{pH}$ in 1-octanol-water; HBD: hydrogen bond donor atoms; HBA: hydrogen bond acceptor atoms.

The predictions of parameters joined with permeability through biological barriers are presented in Table 2 . The distribution $\left(\mathrm{V}_{\mathrm{d}}\right)$ values of all tested compounds are below $2.7 \mathrm{~L} / \mathrm{kg}$, which means that they are predicted to be confined to the blood plasma. Effective permeability $\left(\mathrm{P}_{\text {eff }}\right)$, which reflects the passive transport velocity across the epithelial barrier in the human jejunum, shows high values for jejunal permeability $\left(4.547-9.250 \times 10^{-4} \mathrm{~cm} / \mathrm{s}\right)$. The evaluation of membrane permeability by Madin-Darby Canine Kidney (MDCK) cells shows the values in the range 399-1106.031 $\times 10^{-7} \mathrm{~cm} / \mathrm{s}$ indicating the good apparent membrane permeability. The efficiency of a drug may be affected by the degree to which it binds to the proteins within blood plasma. The human serum albumin binding is a good parameter for evaluating drug availability, and consequently, the efficacy of a drug can be affected by the degree of plasma protein binding. Compared with the recommended values of the unbound drug to proteins within blood plasma (\%Unbnd) $>10 \%$, the results showed a higher percentage of non-bound parts for perezone angelate than for perezone itself, indicating that they can circulate more freely within the bloodstream and hence can have access to the target site.

Table 2. Theoretical values of distribution $\mathrm{V}_{\mathrm{d}}$, effective permeability $\mathrm{P}_{\text {eff }}$, apparent permeability MDCK, percentage of the unbound drug to blood plasma proteins \%Unbnd, blood-to-plasma concentration ratio $\mathrm{RBP}, \mathrm{BBB}$ filter, $\mathrm{BBB}$ partition coefficient $\log \mathrm{BB}$, and the affinity of P-glycoprotein (P-gp) for compounds perezone and perezone angelate.

\begin{tabular}{|c|c|c|c|c|c|c|c|c|}
\hline \multirow{3}{*}{ Compound } & $\mathbf{V}_{\mathrm{d}}$ & $P_{\text {eff }}$ & MDCK & $\%$ Unbnd & RBP & BBB Filter & \multirow{3}{*}{$\log B B^{a}$} & \multirow{3}{*}{$\begin{array}{c}\text { P-gp Sub- } \\
\text { strate/Inhibitor }\end{array}$} \\
\hline & \multicolumn{6}{|c|}{ Expected Values } & & \\
\hline & $(\leq 3.7 \mathrm{~L} / \mathrm{kg})$ & $\begin{array}{c}(\geq 0.5 \\
\left.\mathrm{cm} / \mathrm{s} \cdot 10^{4}\right)\end{array}$ & $\begin{array}{c}(\geq 30 \\
\left.\mathrm{cm} / \mathrm{s} \cdot 10^{7}\right)\end{array}$ & $(>10 \%)$ & $(<1)$ & $\begin{array}{l}\text { (High/ } \\
\text { Low) }\end{array}$ & & \\
\hline Perezone & 0.188 & 6.445 & 399.055 & 7.67 & 0.601 & High & -1.057 & $\mathrm{No} / \mathrm{No}$ \\
\hline Perezone angelate & 1.560 & 4.547 & 1106.031 & 11.45 & 0.787 & High & 0.459 & No/Yes \\
\hline
\end{tabular}

a According to the classification made by Ma et al. [23], high absorption to CNS: logBB more than 0.3; middle absorption to CNS: $\operatorname{logBB} 0.3-(-1.0)$; low absorption to CNS: logBB less than -1.0.

The BBB limits the delivery of chemotherapeutic agents to the brain, and the evaluation of $\mathrm{BBB}$ penetration is crucial for analyzed substances. Two parameters were calculated: $\mathrm{BBB}$ filter and $\log \mathrm{BB}$. Two compounds are characterized by a high probability of cross BBB (Table 2). The highest concentration in the brain is predicted for compound perezone angelate, which is very promising. The affinity to P-gp, an efflux pump, can be evaluated as a biological barrier for toxins, xenobiotics, and potential chemotherapeutic agents [24], because it can expel the molecules from the cells out. As it can be seen in 
Table 2, tested phyto-compounds are not substrates to P-gp, and perezone angelate can even be an inhibitor.

\section{Discussion}

GBM is one of the most lethal and difficult to treat cancers. It has a poor prognosis with maximum 5 -year survival is $7.2 \%$ of patients. Due to its highly infiltrative nature, one of its characteristics is the invasiveness, and despite maximum resection, GBM tumors recur after treatment [25].

Many factors prevent the development of novel compounds to treat GBM such as the BBB, the intrinsic resistance of GBM cells to the induction of cell death, and its complex pathogenesis [17]. The current therapeutic schedule is aggressive, including surgical resection, temozolomide (TMZ), and concurrent adjuvant radiation therapy, and yet, this strategy only delays tumor progression. Furthermore, it causes significant adverse reactions, reducing the patient quality of life [26]. Thus, low-toxicity, effective drugs/protocols are urgently needed.

Immunohistochemical studies showed that PARP-1 protein is over-expressed in GBM cells, being practically undetectable in normal brain tissue [10]. Additionally, it was demonstrated that PARP-1 is overactive in GBM [27] due to high levels of fragmented DNA [28]. Indeed, higher PARP-1 levels have been exhibited an inverse correlation with patient survival [12]. This observation highlights the importance of developing PARP-1 inhibitors for the treatment of GBM [29].

Natural plant products represent a valuable source of anti-neoplastic compounds. Of all the small compounds employed as anti-neoplastic drugs in the last decade, $49 \%$ were phyto-compounds or derivatives. Plant-derived compounds such as alkaloids, taxanes, epipodophyllotoxins, and camptothecins are still the major compounds employed to treat different types of cancers [30].

The cytotoxic activity of perezone angelate was demonstrated, and interestingly, it showed its preference to cancer cells ( 26 fold), which represents the desired characteristic to novel anti-neoplastic compounds [31]. In addition, U373 cells treated with perezone angelate displayed an increase in Annexin- $\mathrm{V}(+) / 7-\mathrm{AAD}(-)$ dyed, which evidenced that apoptosis explains its cytotoxicity and highlighting its importance as an anti-neoplastic compound. Although, in the past, it has not been believed that GBM does not develop metastasis to extracranial organs due to the presence of the BBB, recently, GBM metastasis outside the central nervous system was demonstrated [32]. In this sense, it is essential to emphasize the migration inhibition exhibited by perezone angelate in U373 cells.

As reported previously, perezone exerts pro-apoptotic effects by at least two mechanisms of action: the induction of oxidative stress and PARP-1 inhibition [13]. Figure 8 shows the proposed effects of perezone angelate to explain its pro-apoptotic effects in GBM cells. Perezone and perezone angelate belong to quinones; due to this chemical characteristic, ROS production could be related to an increase in the activity of nicotinamide adenine dinucleotide phosphate (NADPH) oxidase (Nox4), as it has been demonstrated by other quinone derivatives [33]. Furthermore, $\mathrm{NAD}(\mathrm{P}) \mathrm{H}$ :quinone oxidoreductase (NQO1) has been related to Nox4 stimulation [34]. ROS production allows explaining in part the cytotoxic activity of perezone and perezone angelate due to cancer cells being exposed to a relatively high level of ROS compared to that for normal cells, which is primarily due to their active metabolism driven by oncogenic signals [35]. The pharmacological elevation of intracellular ROS represents an effective strategy to target cancer cells selectively. An exogenous source of ROS insult that is within a tolerable level to normal cells could exceed the threshold that cancer cells can endure, leading to the selective eradication of cancer cells [36]. Consequently, excessive ROS levels irreversibly could damage DNA and lipids and ultimately cause the apoptosis of cancer cells [37,38]. 


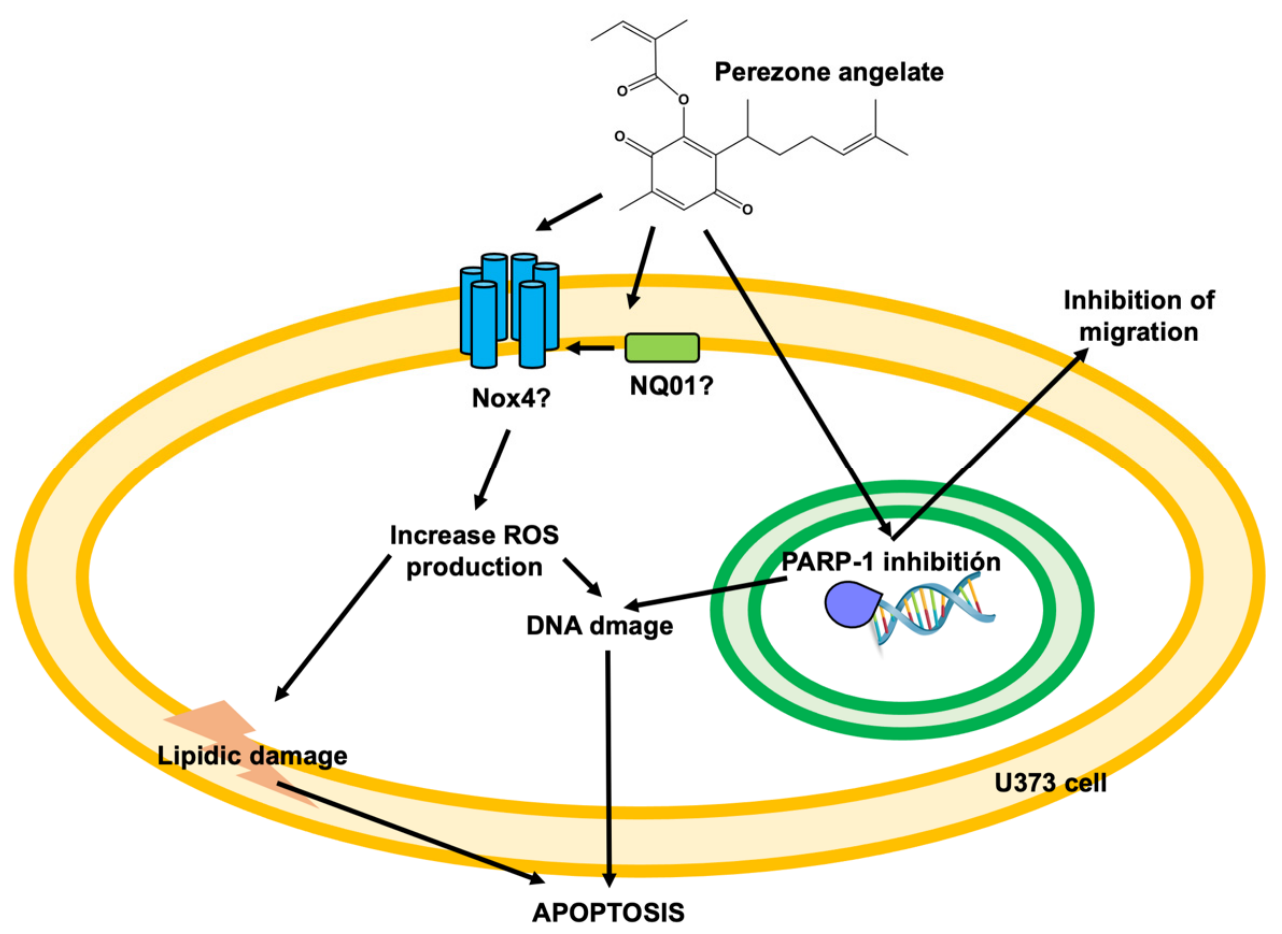

Figure 8. Proposed effects exerted by perezone angelate in U373 cells. Perezone angelate, similar to other quinones, can increase ROS production by Nox4 and NQO1. ROS production can produce both DNA and lipidic damage, resulting in apoptosis induction. In addition, PARP-1 inhibition avoids DNA reparation and contributes to DNA damage, thus contributing to apoptosis induction. Finally, PARP-1 inhibition can impair cell migration.

In addition, it has been shown that perezone produced a reduction in the mitochondria membrane potential in a dose-dependent manner that correlates with its cytotoxic activity [39]. In this sense, perezone and probably its derivatives could alter the mitochondrial electron transport, inducing the apoptosis intrinsic pathway.

Although ROS production is very similar by perezone and perezone angelate, the highest inhibition of PARP-1 by perezone angelate explains its high cytotoxic activity. Particularly, cancer cells have defects in DNA repair pathways; then, tumor cells are susceptible to PARP-1 inhibition [40]. Finally, PARP-1 inhibition could influence cell migration, as previously reported [41].

Docking results allows explaining the affinity of perezone angelate to PARP- 1 by forming a set of non-bonding interactions (Tyr228, Tyr235, Hys201, Ile234, Leu216, Arg217, and Asp105); in this case, the tyrosine residues can display significant $\pi-\pi$ interactions [20] between the aromatic ring of amino acids and the double bond of the side chain. In addition, the acidic protons $(\mathrm{OH})$ of Ile and Arg amino acids contribute to a possible hydrogen bond with the carbonyl groups of the quinone ring. Furthermore, the imidazole moiety of histidine and the carbonyl of aspartic acid can show other meaningful $\pi-\pi$ interactions with the double bond of the quinone ring with the double bond of the angelic moiety, respectively. Consequently, all these interactions are more significant than only the one possible $\pi-\pi$ interaction between the aromatic ring of Tyr246 amino acid and the double bond of the side chain of perezone, which plays an important role [20]. It is important to emphasize that the presence of an angelic moiety allows perezone angelate to fit deeply in the PARP-1 catalytic site, highlighting that the position of the side chain of perezone angelate is placed in the opposite position in comparison to the side chain of perezone, probably promoting the higher non-interactions above, explaining its improved affinity for PARP-1 in comparison with perezone. The affinity of perezone angelate, exhibited by tight close binding, has been shown for other protein-ligand complexes [42]. 
Interesting ADMET studies revealed that perezone angelate showed a reasonable probability of being well absorbed, a high probability of permeating cells, and the BBB. This fact acquires importance because the BBB stops $95 \%$ of molecules from drug development of neurological disorders [43]. Additionally, the determination of affinity to P-gp is a parameter that needs to be considered during the development of drugs to treat brain diseases. P-gp is an efflux pump that can transport molecules from the cells out. From the acquired computational results, it can be highlight that perezone angelate is not a substrate to P-gp, and it can even be an inhibitor, thus pointing to the importance of this compound as an anti-GBM agent.

\section{Materials and Methods}

\subsection{General}

The perezone and perezone angelate extraction was performed as previously described [13]. Melting points $\left({ }^{\circ} \mathrm{C}\right)$ were determined in a Fisher Jones apparatus Scientific Serial No. 810N0220 (Cole-Parmer, IL, USA). The mass spectrums (ESI $19 \mathrm{eV}$ ) were obtained in a microOTOF-Q II mass spectrometer (Agilent Technologies, CA, USA). ${ }^{1} \mathrm{H}$ and ${ }^{13} \mathrm{C}$ spectra were recorded on a Varian Mercury 300 (Varia, CA, USA) $\left({ }^{1} \mathrm{H} 300.08 \mathrm{MHz},{ }^{13} \mathrm{C}\right.$ $75.46 \mathrm{MHz}$ ) in $\mathrm{CDCl}_{3}$ at room temperature with TMS as the internal reference, chemical shifts $(\delta)$ are expressed in ppm and the coupling constants $(J)$ are expressed in Hz. TLC was performed on precoated silica gel Merck Kieselgel $60 \mathrm{~F}_{254}$ plates (Merck KGaA, Darmstadt, Germany) and detected with UV light. All reagents and solvents were analytical grade and were employed without previous purification; they were purchased from Sigma Aldrich Co (Saint Louis, MO, USA).

\subsection{Anti-Proliferative Evaluation}

U373 cells were acquired from ATCC ${ }^{\circledR}$; culture medium, antibiotics, trypsin, and Fetal Bovine Serum (FBS) were acquired from Gibco ${ }^{\circledR}$; and Thiazolyl Blue Tetrazolium Bromide reagent (MTT) was acquired from Sigma Aldrich ${ }^{\circledR}$. The primary mixed glial cell culture was obtained according to procedures reported previously [44]. U373 and microglial cells were cultured in $75 \mathrm{~cm}^{2}$ sterile flask with DMEM 12 supplemented with $10 \%$ FBS. Cells were maintained in a $\mathrm{CO}_{2}$ incubator at $5 \%$ at $37{ }^{\circ} \mathrm{C}$ for all the stages of experiments. Cytotoxic assays of studied compounds and suberoylanilide hydroxamic acid $(10 \mu \mathrm{M})$ as a positive control [15] in U373 and mixed glial cells were performed by MTT assays as it was widely reported [45]. U373 and mixed glial cells were removed from the tissue culture flask by adding $3 \mathrm{~mL}$ of $0.05 \%$ trypsin-EDTA (GIBCO Laboratories) and diluted with fresh media. A cell suspension $\left(100 \mu \mathrm{L}\right.$ containing $5 \times 10^{4}$ cells $)$ was added to the wells of a 96-well culture plate and incubated for $24 \mathrm{~h}$ at $37 \circ \mathrm{C}$ in a $5 \% \mathrm{CO}_{2}$ incubator. Then, $100 \mu \mathrm{L}$ of solutions with increasing concentrations of perezone and perezone angelate diluted in fresh medium containing ethanol $2 \%$ were added to the respective wells, obtaining a final concentrations of $6.25,12.5,25,50,100,200$, and $400 \mu \mathrm{M}(n=8)$ and incubated for an additional $48 \mathrm{~h}$ (final concentration of ethanol 1\%). At this moment, $20 \mu \mathrm{L}$ of the MTT reagent $(5 \mathrm{mg} / \mathrm{mL})$ was added to each well, and the culture plate was incubated for an additional $3.5 \mathrm{~h}$. At the end of the incubation, the medium culture was removed carefully, and the formazan produced by viable cells was diluted by adding $50 \mu \mathrm{L}$ of DMSO to each well. The absorbance was measured at $540 \mathrm{~nm}$ using a UV/Vis spectrophotometer E max Precision microplate reader (Molecular Devices, CA, USA). Absorbances from cells without treatment were considered as $100 \%$ of viability. The concentration-response graphic was obtained for evaluated compounds, and the inhibitory concentration $50\left(\mathrm{IC}_{50}\right)$ was calculated by linear regression analysis.

\subsection{Apoptosis Determination}

The apoptotic cell ratio was measured by Annexin V/7AAD staining followed by flow cytometry analysis. Simultaneous staining of cells with Annexin V/7-AAD allows the discrimination of intact cells (Annexin V-/7-AAD-), early apoptotic (Annexin V+/7-AAD 
-), and late apoptotic or necrotic cells (Annexin V+/7-AAD +) [46]. Briefly, U373 cells (1 mL containing $10^{6}$ per well) were seeded into 24 -well microplates and incubated by $24 \mathrm{~h}$. Then, $1 \mathrm{~mL}$ of solutions with increasing concentrations of perezone and perezone angelate diluted in fresh medium containing $2 \%$ ethanol were added to the respective wells, obtaining a final concentration of 6.25 and $50 \mu \mathrm{M}(n=3)$ and incubated for an additional $48 \mathrm{~h}$ (final concentration of ethanol 1\%), employing cells without treatment as control. At the end of the incubation, cells were trypsinized as previously described and harvested in cytometry tubes. Then, the cells were washed with PBS, suspended in $200 \mu \mathrm{L}$ of binding buffer, which contains $2.5 \mu \mathrm{L}$ of Annexin V (AdipoGen International, USA, Catalog Number AG-40B) and $1 \mu \mathrm{L} 7 \mathrm{AAD}$ (MbI International Corporation, USA, Catalog Number FP00020050), and gently homogenized and incubated for $15 \mathrm{~min}$ at room temperature $\left(25^{\circ} \mathrm{C}\right)$ in the dark. Labeled cells were acquired at 10,000 events in a FACSCalibur flow cytometer (Becton Dickinson, CA, USA), and data were processed by Cell Quest Pro software (Becton Dickinson, CA, USA).

\subsection{Scratch Wound Assay}

Migration of U373 in the presence and absence of perezone and perezone angelate was performed according to the methodology previously described [47]. For this purpose, microglia and U373 of GBM cells were cultured in 24-well microplates $\left(10^{5}\right.$ per well) until confluence was reached, and a thin "wound" was introduced by scratching with a sterile pipette tip [48]. Then, the cells were washed with PBS and cultured with DMEM with FBS $10 \%$ in the absence (control) and presence of target compounds at $6.25 \mu \mathrm{M}(n=3)$. After $48 \mathrm{~h}$ of incubation, pictures were taken by a phase-contrast inverted microscope Olympus IX51.

\subsection{PARP-1 Inhibition Activity}

To corroborate PARP-1 inhibition by perezone angelate, PARP-1 activity was determined in its absence and presence, employing a colorimetric assay kit (BPS Bioscience, USA, Catalog Number 80580), according to manufacturer's instructions, employing olaparib (BPS Bioscience, CA, USA, Catalog Number 27003) as a reference compound at crescent concentrations $(0.00005,0.0001,0.0005,0.001,0.005$, and $0.01 \mu \mathrm{M}, n=3)$. Perezone angelate was employed at final concentrations of $0.5,1,5,10,50$, and $100 \mu \mathrm{M}(\mathrm{n}=3)$. Absorbances were obtained at $450 \mathrm{~nm}$ using a UV/Vis spectrophotometer E max Precision microplate reader (Molecular Devices, CA, USA).

\subsection{ROS Production}

The increase in ROS production induced in U373 cells by treatment with perezone and perezone angelate was determined employing $2^{\prime}, 7^{\prime}$-dichlorofluorescein diacetate ( $\mathrm{DCFH}-$ DA, Sigma-Aldrich, MO, USA, Catalog Number D6883) [47]. Briefly, U373 cells were plated in a 24-well tissue culture plate at a density of $10^{5}$ cells per well. After, the medium was replaced with DMEM containing crescent concentrations of perezone and perezone angelate $(12.5,50,100,200,400$, and $800 \mu \mathrm{M}, n=3)$ and incubated at $37^{\circ} \mathrm{C}$ in a humidified atmosphere of $5 \% \mathrm{CO}_{2}$ for $24 \mathrm{~h}$. Following treatment, the cells were harvested and gently washed with PBS. The cells were stained with DCFH-DA $(10 \mu \mathrm{M})$ and incubated for $30 \mathrm{~min}$ at room temperature in the dark to later be analyzed at $530 \mathrm{~nm}$ on BD FACSAria 1 flow cytometer. A minimum of 10,000 cells per sample was acquired and analyzed in a FACSCalibur flow cytometer (Becton Dickinson, CA, USA), and the data were processed by Cell Quest Pro software (Becton Dickinson, CA, USA).

\subsection{Statistical Analysis}

The obtained results are presented utilizing mean and standard errors (SE) and were analyzed by one-way ANOVA and Tukey's post hoc test, stating a statistically significant difference when $p<0.05$. 


\subsection{Docking Studies}

In order to understand the binding mode of perezone angelate, docking studies were achieved, employing perezone as a control. The 2-dimensional structures of the molecules were drawn employing ChemBioDraw Ultra 12.0 (Version 12.0, PerkinElmer, TX, USA) and HyperChem (Hypercube, Inc., FL, USA)was used to pre-optimize their geometry. Subsequently, the complete optimization of the 3-dimensional structures was achieved using the Gaussian 09 program (Gaussian, Inc., PA, USA) [49] at the theory B3LYP/6311++G(d,p) level [50-55]. The PARP-1 catalytic domain was retrieved from the Protein Data Bank (PDB ID: 1UK0), maintaining only one monomer. Since it was reported that PARP-1 presents high stability, the structure obtained from PDB was employed to perform docking studies [20]. Docking studies were performed employing AutoDock 4.2 software due to its high correlation with experimental data. A directed docking was performed employing a rectangular lattice $(70 \times 70 \times 70 \AA)$ with points separated by $0.375 \AA$ that was centered on the active site of PARP-1. All docking simulations were conducted following parameters previously described [56]. The binding poses with the lowest free energy binding $(\Delta G)$ were analyzed employing AutoDock tools, and the images were created using PyMol.

\subsection{ADMET Predictions Details}

The molecular structures of perezone and perezone angelate were used as input to the mathematical models implemented in the ADMET Predictor ${ }^{\mathrm{TM}}$ version 9 program to generate estimates for each of the drug-likeness properties. In a first instance, the Lipinski rule of five as the filter of toxicity was checked; then, various physicochemical/pharmacokinetic properties such as the topological polar surface area (TPSA), the volume of distribution $\left(V_{d}\right)$, the solubility $\left(S_{w}\right)$, the effective permeability $\left(P_{\text {eff }}\right)$, Madin-Darby Canine Kidney cells apparent permeability (MDCK), the percentage of the unbound drug to proteins within blood plasma (\%Unbnd), the blood-to-plasma concentration ratio (RBP), the blood-brain barrier (BBB filter), the blood-brain barrier partition coefficient $\log C_{\text {brain }} / C_{\text {blood }}(\log B B)$, and the P-glycoprotein (P-gp) affinity were estimated for all compounds at $\mathrm{pH} 7.4$.

\section{Conclusions}

Cell proliferation demonstrated that treatment with perezone angelate significantly induces apoptosis in U373 cells, with low cytotoxicity in rat glial cells, being apoptosis the type of cell death. The inhibition of PARP-1 and the induction of an oxidative stress state in U373 cells by perezone angelate were verified.

The performed docking studies showed that perezone angelate established numerous interactions with the catalytic domain of PARP-1, being promoted by the orientation of angelic moiety and the side chain. ADMET studies revealed that perezone angelate exhibited a reasonable probability of being well absorbed and a high probability to permeate cells and the BBB.

Results obtained reveal the anti-GBM activity of perezone angelate, highlighting the importance of the consequent experimental evaluation of this compound by pharmacokinetics assays to ensure that perezone angelate crosses the BBB, pharmacological evaluation, in an in vivo model of GBM, in addition to toxicological evaluation to determinate its adverse side effects.

Author Contributions: Conceptualization, M.H.-R., E.M.J. and M.I.N.-V.; methodology, M.H.-R., E.M.J., M.E.M.P.; E.R.C., T.Ż. and D.M.; software, T.Ż., and D.M.; validation, J.M. and P.I.M.S.; formal analysis, M.H.-R., E.M.J. and M.I.N.-V.; investigation, M.H.-R., E.M.J. and M.I.N.-V.; resources, E.M.J. and M.I.N.-V.; data curation, E.M.J. and M.I.N.-V.; writing-original draft preparation, M.H.-R., E.M.J. and M.I.N.-V.; writing—review and editing, M.H.-R., E.M.J., M.I.N.-V., T.Ż., D.M. and R.M.R.; visualization, M.H.-R., E.M.J. and M.I.N.-V.; supervision, M.H.-R., E.M.J. and M.I.N.-V.; project administration, M.H.-R., E.M.J. and M.I.N.-V.; funding acquisition, M.H.-R., E.M.J. and M.I.N.-V. All authors have read and agreed to the published version of the manuscript. 
Funding: This research was funded by PAPIIT-UNAM, grant number IN212421, Instituto Politecnico Nacional, grant number SIP20211402, SIP20221071, SIP20221072.

Institutional Review Board Statement: Not applicable.

Informed Consent Statement: Not applicable.

Data Availability Statement: The datasets generated during and/or analyzed during the current study are available upon request to dra.hernandez.ipn@gmail.com and nicovain@yahoo.com.mx.

Acknowledgments: PIM acknowledges Consejo Nacional de Ciencia y Tecnología-Mexico, number, for its master scholarship 628682. The authors are grateful to Dirección General de Cómputo y de Tecnologías de Información y Comunicación (DGTIC-UNAM) for the use of Supercomputer MIZTLI-LANCAD-UNAM-DGTIC-400, PAPIIT-UNAM IN212421.

Conflicts of Interest: The authors declare no conflict of interest.

\section{References}

1. Brodbelt, A.; Greenberg, D.; Winters, T.; Williams, M.; Vernon, S.; Collins, V.P.; Natl, N. Glioblastoma in England: 2007-2011. Eur. J. Cancer 2015, 51, 533-542. [CrossRef] [PubMed]

2. Zhang, J.; Stevens, M.F.G.; Bradshaw, T.D. Temozolomide: Mechanisms of action, repair and resistance. Curr. Mol. Pharmacol. 2012, 5, 102-114. [CrossRef] [PubMed]

3. Sandberg, C.J.; Altschuler, G.; Jeong, J.; Strømme, K.K.; Stangeland, B.; Murrell, W.; Grasmo-Wendler, U.H.; Myklebost, O.; Helseth, E.; Vik-Mo, E.O.; et al. Comparison of glioma stem cells to neural stem cells from the adult human brain identifies dysregulated Wnt- signaling and a fingerprint associated with clinical outcome. Exp. Cell Res. 2013, 319, 2230-2243. [CrossRef] [PubMed]

4. Chamberlain, M.C. Temozolomide: Therapeutic limitations in the treatment of adult high-grade gliomas. Expert Rev. Neurother. 2010, 10, 1537-1544. [CrossRef]

5. Carlsson, S.K.; Brothers, S.P.; Wahlestedt, C. Emerging treatment strategies for glioblastoma multiforme. EMBO Mol. Med. 2014, 6, 1359-1370. [CrossRef] [PubMed]

6. Paw, I.; Carpenter, R.C.; Watabe, K.; Debinski, W.; Lo, H.W. Mechanisms regulating glioma invasion. Cancer Lett. $2015,362,1-7$. [CrossRef] [PubMed]

7. Jain, K.K. Use of nanoparticles for drug delivery in glioblastoma multiforme. Expert Rev. Neurother 2007, 7, 363-372. [CrossRef] [PubMed]

8. Batash, R.; Asna, N.; Schaffer, P.; Francis, N.; Schaffer, M. Glioblastoma Multiforme, Diagnosis and Treatment; Recent Literature Review. Curr. Med. Chem. 2017, 24, 3002-3009. [CrossRef] [PubMed]

9. Curtin, N.J.; Szabo, C. Poly(ADP-ribose) polymerase inhibition: Past, present and future. Nat. Rev. Drug Discov. 2020, 19, 711-736. [CrossRef] [PubMed]

10. Galia, A.; Calogero, A.E.; Condorelli, R.; Fraggetta, F.; La Corte, A.; Ridolfo, F.; Bosco, P.; Castiglione, R.; Salemi, M. PARP-1 protein expression in glioblastoma multiforme. Eur. J. Histochem. 2012, 56, e9. [CrossRef] [PubMed]

11. Salinas, B.; Irwin, C.P.; Kossatz, S.; Bolaender, A.; Chiosis, G.; Pillarsetty, N.; Weber, W.A.; Reiner, T. Radioiodinated PARP1 tracers for glioblastoma imaging. EJNMMI Res. 2015, 5, 123. [CrossRef]

12. Murnyák, B.; Kouhsari, M.C.; Hershkovitch, R.; Kálmán, B.; Marko-Varga, G.; Klekner, Á.; Hortobágyi, T. PARP1 expression and its correlation with survival is tumour molecular subtype dependent in glioblastoma. Oncotarget 2017, 11, 46348-46362. [CrossRef] [PubMed]

13. Hernández-Rodríguez, M.; Mendoza Sánchez, P.I.; Macias Perez, M.E.; Rosales Cruz, E.; Mera Jiménez, E.; Nicolás Vázquez, M.I.; Ruvalcaba, R.M. In vitro and computational studies showed that perezone inhibits PARP-1 and increase ROS levels in K562 cells. Arch. Biochem. Biophys. 2019, 19, 225-234. [CrossRef] [PubMed]

14. Burgueño-Tapia, E.; Castillo, L.; González-Coloma, A.; Joseph-Nathan, P. Antifeedant and phyto toxic activity of the sesquiterpene p-benzoquinone perezone and some of its derivatives. J. Chem. Ecol. 2008, 34, 766. [CrossRef]

15. Lee, J.S.; Kim, H.Y.; Jeong, N.Y.; Lee, S.Y.; Yoon, Y.G.; Choi, Y.H.; Yan, C.; Chu, I.S.; Koh, H.; Park, H.T.; et al. Expression of $\alpha$ B-crystallin overrides the anti-apoptotic activity of XIAP. Neuro Oncol. 2012, 14, 1332-1345. [CrossRef]

16. Johnstone, R.W.; Ruefli, A.A.; Lowe, S.W. Apoptosis: A link between cancer genetics and chemotherapy. Cell 2002, 108, 153-164. [CrossRef]

17. Shergalis, A.; Bankhead, A.; Luesakul, U.; Muangsin, N.; Neamati, N. Current challenges and opportunities in treating glioblastoma. Pharmacol. Rev. 2018, 70, 412-445. [CrossRef]

18. Yuan, Z.; Chen, S.; Sun, Q.; Wang, N.; Li, D.; Miao, S.; Gao, C.; Chen, Y.; Tan, C.; Jiang, Y. Olaparib hydroxamic acid derivatives as dual PARP and HDAC inhibitors for cancer therapy. Bioorg. Med. Chem. 2017, 25, 4100-4109. [CrossRef]

19. Malyuchenko, N.V.; Kotova, E.Y.; Kulaeva, O.I.; Kirpichnikov, M.P.; Studitskiy, V.M. PARP1 Inhibitors: Antitumor drug design. Acta Naturae 2015, 7, 27-37. [CrossRef] 
20. Baptista, S.J.; Silva, M.M.; Moroni, E.; Meli, M.; Colombo, G.; Dinis, T.C.; Salvador, J.A. Novel PARP-1 inhibitor scaffolds disclosed by a dynamic structure-based pharmacophore approach. PLoS ONE 2017, 12, e0170846. [CrossRef]

21. Wills, P.; Warnery, A.; Phung-Ba, V.; Legrain, S.; Scherman, D. High lipophilicity decreases drug transport across intestinal epithelial cells. J. Pharmacol. Exp. Ther. 1994, 269, 654-658.

22. Sakaeda, T.; Okamura, N.; Nagata, S.; Yagami, T.; Horinouchi, M.; Okumura, K.; Yamashita, F.; Hashida, M. Molecular and pharmacokinetic properties of 222 commercially available oral drugs in humans. Biol. Pharm. Bull. 2001, 24, 935-940. [CrossRef] [PubMed]

23. Ma, X.L.; Chen, C.; Yang, J. Predictive model of blood-brain barrier penetration of organic compounds. Acta Pharmacol. Sin. 2005, 26, 500-512. [CrossRef]

24. Lin, J.H.; Yamazaki, M. Role of P-glycoprotein in pharmacokinetics: Clinical implications. Clin. Pharm. 2003, 42, 59-98. [CrossRef]

25. Kong, Y.; Feng, Z.; Chen, A.; Qi, Q.; Han, M.; Wang, S.; Zhang, Y.; Zhang, X.; Yang, N.; Wang, J.; et al. The natural flavonoid galangin elicits apoptosis, pyroptosis, and autophagy in glioblastoma. Front. Oncol. 2019, 9, 942. [CrossRef]

26. Mallick, S.; Gandhi, A.K.; Rath, G.K. Therapeutic approach beyond conventional temozolomide for newly diagnosed glioblastoma: Review of the present evidence and future direction. Indian J. Med. Paediatr. Oncol. 2015, 36, 229-237. [CrossRef]

27. Venere, M.; Hamerlik, P.; Wu, Q.; Rasmussen, R.D.; Song, L.A.; Vasanji, A.; Tenley, N.; Flavahan, W.A.; Hjelmeland, A.B.; Bartek, J.; et al. Therapeutic targeting of constitutive PARP activation compromises stem cell phenotype and survival of glioblastoma-initiating cells. Cell Death Differ. 2014, 21, 258-269. [CrossRef]

28. Bartkova, J.; Hamerlik, P.; Stockhausen, M.T.; Ehrmann, J.; Hlobilkova, A.; Laursen, H.; Kalita, O.; Kolar, Z.; Poulsen, H.S.; Broholm, H.; et al. Replication stress and oxidative damage contribute to aberrant constitutive activation of DNA damage signalling in human gliomas. Oncogene 2010, 29, 5095-5102. [CrossRef]

29. Jannetti, S.A.; Carlucci, G.; Carney, B.; Kossatz, S.; Shenker, L.; Carter, L.M.; Salinas, B.; Brand, C.; Sadique, A.; Donabedian, P.L.; et al. PARP-1-targeted radiotherapy in mouse models of glioblastoma. J. Nucl. Med. 2018, 59, 1225-1233. [CrossRef]

30. Khaw, A.K.; Sameni, S.; Venkatesan, S.; Kalthur, G.; Hande, M.P. Plumbagin alters telomere dynamics, induces DNA damage and cell death in human brain tumour cells. Mutat. Res. Genet. Toxicol. Environ. Mutagenesis 2015, 793, 86-95. [CrossRef]

31. Carr, C.; Ng, J.; Wigmore, T. The side effects of chemotherapeutic agents. Curr. Anaesth. Crit. Care 2008, 19, 70-79. [CrossRef]

32. Ray, A.; Manjila, S.; Hdeib, A.M.; Radhakrishnan, A.; Nock, C.J.; Cohen, M.L.; Sloan, A.E. Extracranial metastasis of gliobastoma: Three illustrative cases and current review of the molecular pathology and management strategies. Mol. Clin. Oncol 2015, 3 , 479-486. [CrossRef]

33. Shi, M.M.; Kugelman, A.; Iwamoto, T.; Tian, L.; Forman, H.J. Quinone-induced oxidative stress elevates glutathione and induces gamma-glutamylcysteine synthetase activity in rat lung epithelial L2 cells. J. Biol. Chem. 1994, 269, 26512-26517. [CrossRef]

34. Nguyen, M.V.; Lardy, B.; Rousset, F.; Hazane-Puch, F.; Zhang, L.; Trocmé, C.; Serrander, L.; Krause, K.H.; Morel, F. Quinone compounds regulate the level of ROS production by the NADPH oxidase Nox4. Biochem. Pharmacol. 2013, 85, 1644-1654. [CrossRef]

35. Waris, G.; Ahsan, H. Reactive oxygen species: Role in the development of cancer and various chronic conditions. J. Carcinog. 2006, 5, 14. [CrossRef] [PubMed]

36. Deavall, D.G.; Martin, E.A.; Horner, J.M.; Roberts, R. Drug induced oxidative stress and toxicity. J. Toxicol. 2012, 2012, 645460. [CrossRef] [PubMed]

37. Gorrini, C.; Harris, I.S.; Mak, T.W. Modulation of oxidative stress as an anticancer strategy. Nat. Rev. Drug Discov. 2013, 12, 931-947. [CrossRef]

38. Hong, Y.; Sengupta, S.; Hur, W.; Sim, T. Identification of Novel ROS Inducers: Quinone Derivatives Tethered to Long Hydrocarbon Chains. J. Med. Chem. 2015, 58, 3739-3750. [CrossRef] [PubMed]

39. Sánchez-Torres, L.E.; Torres-Martínez, J.A.; Godínez-Victoria, M.; Omar, J.M.; Velasco-Bejarano, B. Perezone and its isomer isoperezone induce caspase-dependent and caspase-independent cell death. Phytomedicine 2010, 17, 614-620. [CrossRef]

40. Dietlein, F.; Thelen, L.; Reinhardt, H.C. Cancer-specific defects in DNA repair pathways as targets for personalized therapeutic approaches. Trends. Genet. 2014, 30, 326-339. [CrossRef] [PubMed]

41. Cavone, L.; Aldinucci, A.; Ballerini, C.; Biagioli, T.; Moroni, F.; Chiarugi, A. PARP-1 inhibition prevents CNS migration of dendritic cells during EAE, suppressing th.he encephalitogenic response and relapse severity. Mult. Scler. J. 2011, 17, 794-807. [CrossRef] [PubMed]

42. Hernández-Rodríguez, M.; Correa-Basurto, J.; Gutiérrez, A.; Vitorica, J.; Rosales-Hernández, M.C. Asp32 and Asp228 determine the selective inhibition of BACE1 as shown by docking and molecular dynamics simulations. Eur. J. Med. Chem. 2016, 124, 1142-1154. [CrossRef]

43. Davis, A.M.; Riley, R.J. Predictive ADMET studies, the challenges and the opportunities. Curr. Opin. Chem. Biol. 2004, 8, 378-386. [CrossRef]

44. Orlando, R.A.; Gonzales, A.M.; Royer, R.E.; Deck, L.M.; Vander Jagt, D.L. A chemical analog of curcumin as an improved inhibitor of amyloid abeta oligomerization. PLoS ONE 2012, 7, e31869. [CrossRef] [PubMed]

45. Turkez, H.; Nóbrega, F.R.D.; Ozdemir, O.; Bezerra Filho, C.D.S.M.; Almeida, R.N.; Tejera, E.; Perez-Castillo, Y.; Sousa, D.P. NFBTA A Potent Cytotoxic Agent against Glioblastoma. Molecules 2019, 24, 2411. [CrossRef] [PubMed]

46. Fann, L.Y.; Shih, J.H.; Tseng, J.H.; Huang, H.S.; Hsiao, S.H. CC12 Induces Apoptotic Cell Death and Cell Cycle Arrest in Human Glioblastoma Cell Lines and Mouse Xenograft Model. Molecules 2020, 25, 1793. [CrossRef] [PubMed] 
47. Hernández-Rodríguez, M.; Mendoza Sánchez, P.I.; Macías Perez, M.E.; Rosales Cruz, E.; Mera Jiménez, E.; Aceves-Hernández, J.M.; Nicolás-Vázquez, M.I.; Miranda Ruvalcaba, R. In vitro and computational studies of natural products related to perezone as anti-neoplastic agents. Biochimie 2020, 171-172, 158-169. [CrossRef]

48. Safaee, S.; Fardi, M.; Hemmat, N.; Khosravi, N.; Derakhshani, A.; Silvestris, N.; Baradaran, B. Silencing ZEB2 Induces Apoptosis and Reduces Viability in Glioblastoma Cell Lines. Molecules 2021, 26, 901. [CrossRef] [PubMed]

49. Frisch, M.J.; Trucks, G.W.; Schlegel, H.B.; Scuseria, G.E.; Robb, M.A.; Cheeseman, J.R.; Scalmani, G.; Barone, V.; Mennucci, B.; Petersson, G.A.; et al. Gaussian 09, 2009, Revision C.01; Gaussian, Inc.: Wallingford, CT, USA, 2009.

50. Becke, A.D. Density-functional exchange-energy approximation with correct asymptotic behavior. Phys. Rev. A 1988, 38, 3098-3100. [CrossRef] [PubMed]

51. Lee, C.; Yang, W.; Parr, R. Development of the Colle-Salvetti correlation-energy formula into a functional of the electron density. Phys. Rev. B 1988, 37, 785-789. [CrossRef]

52. Ditchfield, R.; Hehre, W.; Pople, J. Self-Consistent Molecular-Orbital Methods. IX. An Extended Gaussian-Type Basis for Molecular-Orbital Studies of Organic Molecules. J. Chem. Phys. 1971, 54, 724-728. [CrossRef]

53. Henre, W.; Ditchfield, R.; Pople, J. Self-Consistent Molecular Orbital Methods. XII. Further Extensions of Gaussian-Type Basis Sets for Use in Molecular Orbital Studies of Organic Molecules. J. Chem. Phys. 1972, 56, 2257-2261.

54. Hariharan, P.; Pople, J. Accuracy of AH n equilibrium geometries by single determinant molecular orbital theory. Mol. Phys. 1973, 27, 209-214. [CrossRef]

55. Gordon, M. The isomers of silacyclopropane. Chem. Phys. Lett. 1980, 76, 63-168. [CrossRef]

56. Durán, L.A.; Hernández, M.C.; Hernández Rodríguez, M.; Mendieta, J.E.; Trujillo, J.; Correa, J. Mapping myeloperoxidase to identify its promiscuity properties using docking and molecular dynamics simulations. Curr. Pharm. Des. 2012, 19, $2204-2215$. [CrossRef] [PubMed] 